Published in final edited form as:

Semin Oncol. 2013 December ; 40(6): . doi:10.1053/j.seminoncol.2013.09.006.

\title{
Cognitive Effects of Cancer and its Treatments at the Intersection of Aging: What do we Know; What do we Need to Know?
}

Jeanne S. Mandelblatt, MD, MPH ${ }^{1}$, Arti Hurria, MD², Brenna C. McDonald, PsyD ${ }^{3}$, Andrew J. Saykin, PsyD ${ }^{4}$, Robert A. Stern, PhD $^{5}$, John W. VanMeter, PhD $^{6}$, Meghan McGuckin, MS ${ }^{7}$, Tiffani Traina, $\mathbf{M D}^{8}$, Neelima Denduluri, $\mathbf{M D}^{9}$, Scott Turner, $\mathbf{M D}^{10}$, Darlene Howard, $\mathbf{P h D}^{11}$, Paul B. Jacobsen, $\mathrm{PhD}^{12}$, and Tim Ahles, $\mathrm{PhD}^{13}$ For the TLC Study (Thinking and Living with Cancer)

${ }^{1}$ Professor, Department of Oncology and Associate Director for Population Sciences, Lombardi Comprehensive Cancer Center, Georgetown University, Washington, DC

${ }^{2}$ Associate Professor of Oncology, Department of Medical Oncology and Therapeutics Research, City of Hope Comprehensive Cancer Center, Duarte, California

${ }^{3}$ Assistant Professor, Center for Neuroimaging, Department of Radiology and Imaging Sciences and the Melvin and Bren Simon Cancer Center, Indiana University School of Medicine Indianapolis, Indiana

4Professor of Radiology and Imaging Sciences, Center for Neuroimaging, Department of Radiology and Imaging Sciences and the Melvin and Bren Simon Cancer Center, Indiana University School of Medicine Indianapolis, Indiana

${ }^{5}$ Professor, Departments of Neurology and Neurosurgery and Director, Clinical Core, BU Alzheimer's Disease Center, Boston University School of Medicine, Boston, Massachusetts

${ }^{6}$ Associate Professor, Department of Neurology, Georgetown University Medical Center, Georgetown University, Washington, DC

7Project Coordinator, Department of Oncology, Lombardi Comprehensive Cancer Center, Georgetown University, Washington, DC

${ }^{8}$ Assistant Attending Physician, Department of Medicine, Memorial Sloan Kettering Cancer Center, New York, NY

${ }^{9}$ Clinical Assistant Professor, Department of Medicine, Georgetown University; Virginia Cancer Specialists, US Oncology, Arlington, VA

\footnotetext{
(c) 2013 Elsevier Inc. All rights reserved.

Please Address Correspondence and Requests for Reprints to: Jeanne Mandelblatt, MD, MPH, Lombardi Comprehensive Cancer Center, 3300 Whitehaven Blvd, Suite 4100, Washington, DC 20007, USA, 202-687-0812/fax 202-687-0305, mandelbj@georgetown.edu.

Financial disclosures:

Hurria: Seattle Genetics, Amgen Pharmaceuticals, and Genetech (consultation); Glaxo Smith Kline, Abraxis Bioscience, and Celgene (research support)

All remaining authors have declared no conflicts of interest

Publisher's Disclaimer: This is a PDF file of an unedited manuscript that has been accepted for publication. As a service to our customers we are providing this early version of the manuscript. The manuscript will undergo copyediting, typesetting, and review of the resulting proof before it is published in its final citable form. Please note that during the production process errors may be discovered which could affect the content, and all legal disclaimers that apply to the journal pertain.
} 
${ }^{10}$ Professor, Department of Neurology, Georgetown University Medical Center, Georgetown University, Washington, DC

${ }^{11}$ Professor, Department of Psychology, Georgetown University, Washington, DC

${ }^{12}$ Associate Center Director, Division of Population Science, Moffitt Cancer Center, Tampa, FL

${ }^{13}$ Attending, Department of Psychiatry and Behavioral Sciences, Memorial Sloan-Kettering Cancer Center, New York, NYProfessor of Psychology in Psychiatry, Department of Psychiatry, Weill Cornell Medical College, New York, NY

\section{Abstract}

There is a fairly consistent, albeit non-universal body of research documenting cognitive declines after cancer and its treatments. While few of these studies have included those 65 and older, it is logical to expect that older patients are at risk of cognitive decline. In this paper, we use breast cancer as an exemplar disease for inquiry into the intersection of aging and cognitive effects of cancer and its therapies. There are a striking number of common underlying potential biological risks and pathways for the development of cancer, cancer-related cognitive declines, and aging processes, including the development of a frail phenotype. Candidate shared pathways include changes in hormonal milieu, inflammation, oxidative stress, DNA damage and compromised DNA repair, genetic susceptibility, decreased brain blood flow or disruption of the blood-brain barrier, direct neurotoxicity, decreased telomere length, and cell senescence. There are also similar structure and functional changes seen in brain imaging studies of cancer patients and those seen with "normal" aging and Alzheimer's disease. Disentangling the role of these overlapping processes is difficult since they require aged animal models and large samples of older human subjects. From what we do know, frailty and its low cognitive reserve seem to be a clinically useful marker of risk for cognitive decline after cancer and its treatments. This and other results from this review suggest the value of geriatric assessments to identify older patients at the highest risk of cognitive decline. Further research is needed to understand the interactions between aging, genetic predisposition, lifestyle factors and frailty phenotypes to best identify the sub-groups of older patients at greatest risk for decline and to develop behavioral and pharmacological interventions targeting this group. We recommend that basic science and population trials be developed specifically for older hosts with intermediate endpoints of relevance to this group, including cognitive function and trajectories of frailty. Clinicians and their older patients can advance the field by active encouragement of and participation in research designed to improve the care and outcomes of the growing population of older cancer patients.

\section{Introduction}

Cancer is largely a disease of older age. ${ }^{1}$ With the graying of America, one in five individuals will be 65 years or older ("older") by the year $2030 .{ }^{2}$ As these individuals develop cancer, they are at risk of experiencing adverse cognitive effects of this disease and its local and systemic therapies. Cancer-related cognitive declines were first described three decades ago, ${ }^{3}$ and a fairly consistent, albeit not universal, picture of these deficits has evolved to the present. ${ }^{4-6}$ There are a striking number of common underlying biological risks and pathways for the development of cancer and cancer-related cognitive declines and aging processes. These commonalities may have implications for the clinical care of the growing number of older cancer patients. ${ }^{5,7-13}$

Breast cancer is an ideal disease for inquiry into the intersection of aging and cognitive effects of cancer and its therapies because it is the second most common cancer in women, ${ }^{14}$ with more than $50 \%$ of new cases occurring among women 65 and older, ${ }^{1,15}$ and its treatment has historically included a high rate of use of systemic chemotherapy and/or 
hormonal therapy. There is also the largest body of empiric evidence about the cognitive aspects of breast cancer and its treatments, compared to other cancers.

Most controlled investigations and meta-analyses of the studies of the effects of breast cancer therapy on cognitive function report decrements in one or more domains, including verbal working memory, visual memory and visual-spatial domains, executive function (including working memory), and/or processing speed compared to pre-treatment, cancer and/or population controls. ${ }^{5,6,16-21}$ These cognitive declines have been observed to persist for variable periods of time from one ${ }^{16,22}$ to as many as 10-20 years post-treatment. ${ }^{23-25}$ Unfortunately, the mean age in the most recent meta-analysis of the cognitive effects of breast cancer therapy was 53 years ${ }^{6}$ and only a few studies have been designed to examine outcomes for older patients. ${ }^{4,26-29}$

High rates of objective and subjective cognitive impairment have been reported in most studies of older breast cancer patients. ${ }^{28-30}$ However, variable rates of cognitive decline have been noted in other studies that include older cancer patients. 4,27,31-34 All of these reports have had small samples of older patients (range of $n=13-50$ ), ${ }^{4,27,30}$ some have focused on patients treated in mid-life and evaluated at age 65 or older ${ }^{28}$ and only one was able to examine age interactions. ${ }^{7}$ In that study, Ahles and colleagues found that women ages 60 to 70 with low baseline cognitive reserve that underwent chemotherapy had lower performance on tests of processing speed compared with those not receiving chemotherapy and controls (Figure 1). ${ }^{5,7}$ Thus, it is possible that only a sub-group of older patients (or patients at any age) experience cognitive effects after systemic cancer therapy. $6,7,35$ However, there is only limited empiric evidence about the risk factors that define vulnerable groups, and even less for older cancer patients.

In this paper, we present a framework for considering the relationships among the key constructs involved in evaluating the cognitive effects of cancer and its treatments at the intersection of aging, review some potential shared biological mechanisms and how they fit within current theories of aging, discuss methodological challenges in conducting research on this topic in the older population, and summarize the clinical implications of these results for the care of the growing older population diagnosed with and surviving with cancer.

\section{Aging, Frailty, and Cognitive Decline}

Aging is the net effect of the temporal accumulation of damage to cellular processes and systems, loss of compensatory mechanisms, and increased vulnerability to disease and death. Closely aligned to this definition is the clinical concept of frailty, which can be considered a phenotype of aging. This phenotype is characterized by a diminished biologic reserve and resistance to stressors caused by collective declines across physiologic systems, leading to vulnerability to insult and adverse outcomes. ${ }^{36}$

Fried and her colleagues initially described the frail phenotype as having three out of five of the following criteria: weight loss, exhaustion, low physical activity, slow walking gait, and poor grip strength. ${ }^{36}$ Although this original phenotype did not include cognitive function, it is now widely recognized as one of the key factors involved in the impaired physiologic pathways leading to frailty. ${ }^{37-40}$ The converse is also true: individuals with frailty are more vulnerable to the development of cognitive disorders (e.g., Alzheimer's disease) and to cognitive decline after stressors such as cancer therapy (Figure 2). ${ }^{7,24,41}$ Further, frailty and cognitive deficits each are independently associated with high risks of dependence and mortality. For instance, selected measures of cognitive function, such as the Trail Making Test, have been noted to predict physical frailty as measured on the Short Physical Performance Battery, as well as mortality in older individuals in the general population. ${ }^{42}$ Identifying the biological underpinnings of these associations and disentangling their 
temporal and etiological relationships is an important research priority and an area of nascent discovery.

From what we do know, it seems that there are several potential common pathways. Observations that biomarkers of inflammation such as high C-reactive protein (CRP) and high interleukin-6 (IL-6) are seen in the frail phenotype, ${ }^{43}$ senescence, $9,44,45$ and cognitive declines in Alzheimer's disease ${ }^{46}$ and after cancer therapy ${ }^{22,47}$ suggest one potential common biological pathway. There is also overlap in the genotypes (e.g., APOE polymorphisms) associated with cancer related cognitive declines, Alzheimer's and their associated frailty phenotypes. ${ }^{24,48-50}$ Further support of the concept of common underlying biological processes is based on the recent body of evidence demonstrating similar brain structural alterations in aging, cancer-related cognitive declines, and Alzheimer's disease, including decreases in overall brain volume, gray matter, white matter connectivity and hippocampal volume. ${ }^{5,13,25,51-54}$ Finally, the observation that cancer patients have lower cognitive function than expected based on age and education even before any treatment 5,55 suggests, as depicted on Figure 3, that there are common underlying risks for cancer and cognitive decline, and that both are in part age-related phenomena. In the next section we highlight some of the research on the potential common pathways related to the pathogenesis of cognitive decline, frailty and aging.

\section{Common Biological Pathways}

Most consider that cancer and aging are linked, although the molecular mechanisms responsible for the increasing risk of cancer with increasing age and frailty are not completely understood. Aging is clearly related to neurodegenerative diseases such as Alzheimer's disease. It is also biologically plausible that cancer and neurodegenerative conditions are linked, since they have some common pathways related to the cell cycle (e.g., p53 proteins and the Pin1 protein), albeit in opposing directions, with cancer related to proliferation and Alzheimer's related to cell death. ${ }^{56-58}$

In this broad context, the precise biological mechanisms and pathways underpinning cognitive decline after cancer and/or its treatments remain uncertain. The common "candidate" pathways include changes in hormonal milieu, inflammation, oxidative stress, DNA damage and compromised DNA repair, genetic susceptibility, decreased brain blood flow or disruption of the blood-brain barrier, direct neurotoxicity or damage to specific brain regions, decreased telomere length, and cell senescence (Figure 3). 5,8,51,59-62

\section{Hormones}

Hormonal levels decrease over the lifespan and have been implicated in cognitive function in non-cancer populations 63 and hormonal replacement therapy has been noted to decrease the risk of Alzheimer's disease by up to 29\%. ${ }^{64-69}$ Breast cancer hormonal therapies act by blocking or lowering hormonal levels in individuals with estrogen receptor positive tumors. Possible mechanisms by which hormonal treatment could affect cognition include decreases in cholinergic activity ${ }^{66,70}$, reduced induction of serotonin receptors, ${ }^{71}$ direct toxic effects on dendrites and synaptic connectivity, ${ }^{72,73}$ and changes in lipids. ${ }^{74}$ Since estrogen also has anti-oxidant effects ${ }^{75,76}$ and maintains telomere length ${ }^{77}$, breast cancer hormonal therapies that block estrogen may also exert their negative effects on cognition via accelerating aging.

The role of hormonal change is supported by the body of research demonstrating decrements in cognitive function among women receiving systemic hormonal therapy, either alone or with chemotherapy. ${ }^{78-83}$ However, effects are not universal and may not be observed with all hormonal therapies. For instance, a recent clinical trial reported by Schilder and her colleagues noted cognitive declines in verbal memory and executive function among women 
treated with tamoxifen but not exemestane. ${ }^{79}$ This result is biologically plausible since estrogen can be neuroprotective and estrogen receptors, the target of tamoxifen and other drugs in its class, are found in large numbers in the frontal lobe and hippocampus; ${ }^{84-87}$ these same areas have been noted to have abnormalities on imaging studies. ${ }^{53,88}$ In contrast, exemestane, one type of aromatase inhibitor, blocks conversion of androgens into estrogens, and its metabolites have mild androgenic properties. Since androgens can enhance cognition, this may be one explanation for the relative lack of impairment due to this particular hormonal regimen. However, results for the effect of other hormonal therapies on cognition have been inconsistent. ${ }^{7980,81}$ One intriguing result of the Schilder trial comparing hormonal therapies was a preliminary result that tamoxifen had larger effect sizes and affected a greater number of cognitive domains in women 65 and older compared to women less than 65 years of age. ${ }^{79}$ It will be important to replicate this finding and to examine the role of different types of estrogen receptors in brain tissue, especially if hormonal therapies will be recommended for longer periods of administration..

\section{Inflammation}

Inflammatory responses involved in aging, cancer and/or generated by cancer-directed agents have been suggested as one pathway for cognitive declines via triggering of neurotoxic cytokines. ${ }^{89}$ A study by Ganz and colleagues examined several proinflammatory cytokines in breast cancer patients. They found that soluble tumor necrosis factor-alpha receptor II (sTNF-RII) was significantly higher in those who received chemotherapy compared to those who did not, but that levels declined over time. Of note, the higher sTNF-RII levels were associated with self-reported memory complaints and decreased brain metabolism in frontal regions on positron emission tomography (PET) scans, and subjective cognitive function improved as sTNF-RII levels declined over the one year of follow-up. ${ }^{22}$ Other inflammatory cytokines were not associated with neurocognition and the relationships were not significant after controlling for fatigue levels, suggesting that fatigue and cognitive declines might both share a common inflammatory etiology. Unfortunately, assessments occurred after initial therapy, so that the separate effects of having cancer could not be assessed; the study also lacked a control group and was focused on the effects of menopause and hormonal therapy in younger women, so may not be generalizable to pathways related to aging. Also, since aging is associated with the accumulation of multi-morbidities that affect or are the result of inflammatory pathways (e.g., diabetes, heart disease), ${ }^{90}$ it will require careful sampling and sub-group analysis to segregate the impact of inflammation related to cancer in studying cognitive outcomes and to control for fatigue components of frailty phenotypes. This will be an important area for future research.

\section{DNA Damage and Repair}

Oxidative DNA damage, as measured in lymphocytes, has been noted in breast cancer patients both before any systemic therapy and after chemotherapy. ${ }^{13,91,92}$ Conroy and her colleagues recently conducted an innovative study with breast cancer survivors and matched non-cancer controls. The sample ranged in age from 41 to 79 years old; the cancer patients were three to 10 years post-treatment. They found that oxidative DNA damage was higher in patients than controls and that DNA damage was correlated with self-reported cognitive problems, lower cognitive function and less frontal gray matter density and brain activation on functional MRI (fMRI). ${ }^{13}$ While only small numbers of patients were assessed $(n=48)$, the result is interesting because oxidative DNA damage and diminished DNA repair mechanisms are also markers of senescence, ${ }^{44}$ and are seen in age-related diseases including Parkinson's disease, mild cognitive impairment, and Alzheimer's disease. ${ }^{93,94}$ Hormonal therapies may also be associated with increased DNA damage. ${ }^{95}$ The exact mechanisms and pathways whereby DNA damage leads to cognitive decline is unclear, but 
it is postulated to be related to either production of defective proteins that lead to neuronal apoptosis 96 or problems in transcription that cause the loss of required gene protein products. ${ }^{97}$ It should also be noted that DNA damage can trigger cytokine release, which in turn increases oxidative stress and further DNA damage. ${ }^{98,99}$ How these processes are affected by age-related DNA damage or chronic inflammation related to other non-cancer comorbidities is unclear and will need to be disentangled to fully understand mechanisms of cognitive decline in older cancer patients.

\section{Genetic Factors}

There is considerable variability across individuals in presence and extent of cognitive changes associated with cancer and cancer treatment. The observation that a subgroup of patients appears differentially affected strongly suggests that genetic influences may modulate the influence of exposure to cancer pathophysiology or treatment. ${ }^{12,51,100}$ Polymorphisms of the APOE and COMT genes have been studied for associations with cognitive changes after cancer treatment ${ }^{21,24}$ but numerous other candidate genes may play a role. ${ }^{51,100}$ Many of these genes have a role in age-related cognitive decline.

$A P O E$ is located on chromosome 19 and was first identified as a risk for Alzheimer's disease in the early 1990's, ${ }^{101}$ and it remains the leading known genetic risk for this disease. It codes for apolipoprotein E (ApoE), a complex lipoprotein known to play a role in lipid transport and regulation of inflammatory immune activity, among other biological functions. In the central nervous system, ApoE is also involved in amyloid beta metabolism, a key substrate of Alzheimer's, as well as neural repair processes after brain injury and brain plasticity. $A P O E$ has three alleles ( $\varepsilon 2, \varepsilon 3$ and $\varepsilon 4$ variants) which are, in turn, determined by two single nucleotide polymorphisms (SNPs) - rs7412 and rs429358. APOE $\varepsilon 4$ is the adverse risk allele that confers risk of Alzheimer's 102 and is associated with poor recovery after stroke and trauma. ${ }^{103,104}$

Ahles and colleagues noted that breast cancer survivors who received chemotherapy and were $A P O E \varepsilon 4$-positive had greater cognitive decline in the visual-spatial and visual memory domains compared to $\varepsilon 4$-negative survivors receiving this treatment (average age 56). ${ }^{24}$ However, the relationship between $A P O E$ and cognitive outcomes has not been consistent in the few other studies to examine this question among breast cancer patients, ${ }^{54}$ although they were often not designed to have power to detect genetic influences. APOE has also been noted to be a risk factor for the development of breast cancer ${ }^{105}$ or a moderator of fat and obesity risks of breast cancer. ${ }^{106}$ If $A P O E$ polymorphisms are linked to risk of disease, especially more aggressive types of disease or larger tumors (seen in obese women), and women with these tumors are differentially more likely to receive chemotherapy, then $A P O E$-post treatment relationships may be confounded.

Adding to the complexity are the observations that polymorphisms of estrogen receptors also influence ApoE synthesis 107,108 and interact with ApoE in risk for Alzheimer's, ${ }^{109}$ so there may be treatment-gene interactions in producing cognitive decline. This idea is supported by one study of non-cancer patients where hormone replacement therapy was only protective of cognitive decline among women without an ApoE $\varepsilon 4$ allele. ${ }^{110}$ It will be important to test these hypotheses directly in future studies of cognitive outcomes in older breast cancer patients receiving different types of hormonal therapy, especially as recommendations for this modality are extended from five to ten years of treatment. ${ }^{111,112}$

The other gene studied specifically in cancer patients with regard to cognitive outcomes is COMT, located on chromosome 22q11. COMT codes for catechol-O-methyltransferase, an enzyme that metabolizes catecholamine neurotransmitters including dopamine, epinephrine, and norepinephrine; the Val158Met SNP (rs4680) in COMT (substitution of methionine with 
valine) increases dopamine break down and decreases synaptic neurotransmitter levels. COMT plays an important role in dopamine regulation in the frontal lobes and has been shown to be associated with executive function in normal controls. In a study of cancer and cognition by Small and colleagues, breast cancer patients treated with chemotherapy who were COMT-valine carriers performed worse on measures of attention compared to COMTmethionine homozygotes, although the average age of these women was $51 .{ }^{21}$ Of note, Lindenberger has found an age interaction with the COMT gene. ${ }^{113}$

Brain-derived neurotrophic factor $(B D N F)$ is another gene involved in neuron growth and repair and is found primarily in the prefrontal cortex and hippocampus. ${ }^{114,115} \mathrm{~A}$ functional polymorphism of $B D N F$ has been associated with lower memory and executive function in non-cancer populations. ${ }^{116-118}$ Lindenberger and colleagues observed interactions between $B D N F, C O M T$, and age. ${ }^{113}$ This result underscores the complex interplay between aging, declining reserve and genetic factors. Overall, the role of $B D N F$ and other neural and glial growth factors appears promising for investigation in cancer patients.

Some other single nucleotide polymorphisms ( $S N P$ s) have also been implicated in cognitive decline among cancer patients. In a preliminary report, Ganz reported that the TNFalpha-308 promoter $S N P$ was associated with the level of self-reported memory problems after cancer treatment, ${ }^{119,120}$ consistent with the posited role of an inflammatory mechanism in the etiology of this syndrome.

Variations in genes that affect blood-brain barrier transporter could also be involved in mediating the direct neuro-toxicity of some chemotherapeutic agents, since in animal models, only small doses are needed to produce neuronal cell death. ${ }^{51,61,121}$ For example, the multidrug resistance 1 (MDRI) gene encodes the protein P-glycoprotein (P-gp); P-gp influences the level of a chemotherapeutic agent in the brain. ${ }^{51,122}$ Polymorphisms of the MDRI gene (e.g., C3435T in exon 26) ${ }^{123}$ could influence $\mathrm{P}$-gp function such that a sufficient amount of drug reaches neuronal cells to directly cause toxicity.

An emerging area of genetic investigation is related to microRNAs (miRNA). miRNAs are very small non-coding RNAs that are becoming increasingly recognized as playing a major role in regulating gene expression and cell metabolism in cancer and neurodegenerative disease. ${ }^{48}$ Holohan recently examined the relationship between the functional roles of miRNAs in cancer and Alzheimer's disease as two age associated disorders. ${ }^{48}$ Numerous other candidate genes and pathways are thought to potentially may play a role in cognitive changes associated with cancer and cancer treatment and have been reviewed previously. ${ }^{51,100}$

\section{Alterations in Blood-Brain Barrier and other Vascular Factors}

Many systemic chemotherapies including anthracyclines do not appear to cross the bloodbrain barrier. Exceptions may include those included in the cyclophosphamide, methotrexate and fluorouracil (CMF) regimen. ${ }^{89,124}$ Since older patients may remain more likely to get CMF regimens due to the higher cardiac and other toxicity profiles seen with anthracycline regimens, older breast cancer patients may be at higher risk for direct neurotoxicity, underscoring the need to carefully consider specific agents when studying outcomes among older patients.

Other factors that affect vascular function ${ }^{125}$ have been implicated in aging and cognitive performance, such as smoking and low levels of high density lipoproteins (HDL). ${ }^{10,126,127}$ Interestingly, nicotine and statin medications seem to be protective of cognitive decline, so that these relationships are not straightforward. ${ }^{125,128}$ Similar to observations in cancer patients, there also appear to be interactions between cerebrovascular disease or diabetes and 
the ApoE $\varepsilon 4$ allele in producing memory impairments. ${ }^{17,18,129}$ These observations could help to identify subgroups of older cancer patients at risk for cognitive declines related to vascular factors.

\section{Structural and Functional Brain Changes on Neuroimaging}

To the extent that cancer treatments may accelerate or mimic the effects of aging, some overlap in brain structures affected by cancer treatments and aging is expected. Imaging studies have demonstrated that total gray matter volume reliably decreases with advancing age, with regional changes exhibited mainly in the frontal cortex and in regions around the central sulcus, including the hippocampus. ${ }^{130}$ Lower hippocampal volume is related to memory functioning and has been observed in breast cancer patients after treatment. ${ }^{131}$ White matter also diminishes with increasing age. ${ }^{130,132}$ Reduction in volume of frontal brain structures and changes in the integrity of white matter tracts have been reported after chemotherapy, as have alterations in brain activation on functional neuroimaging. ${ }^{12,13,25,133-139}$ Of note, there appear to be pre-treatment cancer effects as well, with altered frontal cortex activation during fMRI tasks in breast cancer patients relative to healthy controls. ${ }^{140,141}$ Similar abnormalities related to breast cancer treatment have been observed using functional positron emission tomography (PET) and electrophysiological methods. ${ }^{142}$ There are also differences in resting state between breast cancer patients and controls. ${ }^{143}$ However, all of these imaging studies have been among breast cancer patients under age 65 . Imaging studies in older patients will be critical to confirming the brain structural links between cancer and aging.

\section{Telomeres}

Over the life course, telomeres shorten with each cell replication, ultimately leading to cell senescence (see below) and apoptosis, so that leukocyte telomere length has been used an a marker of cellular age with shorter length indicating a greater degree of senescence. As such, telomere health has been linked to aging, Alzheimer's disease severity, cancer risk, and mortality rates. ${ }^{144}$ For instance, patients with Alzheimer's have been observed to have shorter telomeres than controls, and shorter length has also been associated with greater disease severity. ${ }^{144}$ Cancer chemotherapy also has effects on telomere length, and this could be another common pathway between aging and cancer related cognitive decline via effects on replicating cells. ${ }^{62,145-147}$

\section{Senescence}

Senescence refers to the state of cells that are metabolically active but can no longer replicate. Many of the same factors that we have been discussing as common potential causal pathways to aging and to cognitive decline after cancer and cancer therapy have been implicated as stressors that can lead to cell senescence. ${ }^{8,148}$ Senescent cells evoke inflammatory responses and accumulate at sites of pathology, including Alzheimer's plaques. ${ }^{8,148}$ Senescent cells can also be considered a biomarker of the frailty phenotype ${ }^{9}$ that places cancer patients at risk for cognitive declines. The targets for cancer treatments could potentially negatively affect biologic markers of aging such as senescence, since there is a reciprocal relationship between tumor suppression and senescence in healthy cells. For instance, increases in tumor suppressor mechanisms through p53/p21 and p16INK4a/pRB and other pathways are under investigation as leverage points for treat cancer but are associated with increased cell senescence, and could therefore accelerate aging and increase risk for cognitive toxicity. ${ }^{8,148}$ Thus, it will be important to consider senescence and the translation of the basic science of aging into clinical studies of the impact of cancer and new systemic cancer therapies on cognitive outcomes in older patients. 
Taken together, this body of mechanistic research suggests that biologic processes underlying cancer, the impact of cancer treatments, aging, and cognitive decline are linked, and that cancer treatments may actually accelerate the aging process. ${ }^{62}$ As with most conditions, not all breast cancer patients develop cognitive effects related to their cancer or its treatments, underscoring the need to identify the sub-group with the highest risk of cognitive decline. Overall, age-related phenotypes such as frailty and diminished cognitive and overall reserve and biomarkers reflecting senescence and aging processes are logical candidates for identifying patients at high risk of cognitive decline. ${ }^{5}$

\section{Models of Aging}

The constellation of intersecting factors related to cancer-related cognitive decline, frailty, and aging raises several provocative questions: If cancer therapy impacts cognitive function, does the trajectory of dysfunction parallel that of normal aging (phase shift hypothesis), or is the trajectory of dysfunction accelerated in comparison to normal aging (accelerated aging hypothesis)? ${ }^{5}$ Is the lowest common denominator a depletion of reserve leading to a frail phenotype (reliability theory of aging)?

As depicted on Figure 4, the phase shift theory postulates that cancer patients experience decrements in cognitive function compared to their non-cancer counterparts, and those decrements remain constant over time. Alternatively, if cancer and its treatment are actually accelerating aging processes, we would expect the slope of decline in cognitive function would be steeper for patients relative to their non-cancer cohorts. The relativity theory of aging ${ }^{149}$ further posits that declines in cognitive function are a function of overall system redundancy and repair (i.e., net reserve), so that patients who are frail would be expected to show the steepest decline and those with less frailty (and greater reserve) would decline at a slower rate. These differences would not be appreciated by only examining the average trajectory (see also Figure 2). Beyond cancer and cancer therapies, access to healthcare and management of chronic disease and lifestyle factors such as exercise or smoking would affect reserve and system failures. In the reliability theory, frailty would be considered as the failures of multiple systems.

An important strength of the reliability theory for studying cognitive effects of cancer and its treatments in older patients is that it does not depend on a given treatment affecting a specific biologic pathway. ${ }^{5}$ As noted by Ahles and colleagues, different patterns of failure across various biologic systems may confer more or less risk of specific treatments for each patient: one patient may be vulnerable to DNA damaging effects of a particular chemotherapy regimen, whereas another patient may be susceptible to the impact on the hormonal milieu of endocrine treatments. Implicit in this conceptualization is the idea that the trajectories of cognitive decline are dependent on pre-morbid cognitive and other system reserve. One practical implication for future research is the need for pre-treatment assessments and evaluation of self-reported function prior to cancer diagnosis. Viewed through the lens of aging theories, researchers may also want to specifically investigate discrete trajectories, rather than group averages when assessing temporal trends in cognitive function. ${ }^{150}$

\section{Measurement Issues}

There are many methodological considerations in studying the complex interactions between cancer, cancer therapy and cognitive function. In this section we highlight several concerns specific to evaluations of the role of aging and needs of older patients. For excellent reviews of international consensus panels on methods for studying cancer and cognition the reader is referred to summaries of the International Cognition and Cancer Task Force. ${ }^{35,142,151}$ 
First, this is a field that will require transdisciplinary collaboration between basic scientists and clinical researchers, including gerontologists and geriatricians. One obvious methodological basic science issue is the need to use older animals or systems that mimic aging systems, since the aging tissue microenvironment can have important effects on agerelated chronic disease phenotypes and cognitive processes. ${ }^{9}$ Kirkland has suggested use of chronologically-aged mouse chronic disease models, progeroid bred with chronic disease mouse models, or chronic disease mouse models treated with "age accelerating" interventions such as high fat diets. ${ }^{9}$

Likewise, in human studies, the greatest challenge to understanding the complex interplay of cancer and its therapy against the backdrop of aging processes is the lack of inclusion of the older age group in many research studies and clinical trials. As noted in the preceding sections, it will be important to include sufficient numbers of older patients to capture variability in reserve and frailty, effects of different classes of therapeutic agents, and the impact of other chronic diseases and biological processes.

To fully understand the trajectory of cognitive declines, it is also essential to assess baseline function and follow patients longitudinally. A well-matched non-cancer control group is also essential to valid inference, but can be difficult in older populations given the high rates of cognitive disorders and other chronic diseases and medications that affect cognition. Thus, well specified inclusion criteria and matching based on multi-morbidities should be considered. Care must be taken to use instruments that are validated in the target population. Moreover, issues of "cognitive reserve" 7,152 must be taken into account through appropriate control for estimated premorbid ability, educational attainment, and other proxy measures of this construct. Although many investigators strive for abbreviated cognitive assessments with older patients, in part because of the need to avoid potential fatigue effects from longer test batteries, it is critical that the brevity is balanced by an adequate evaluation of the cognitive domains hypothesized to be impacted by treatment (Table 1).

Recruiting older participants also requires sensitivity to needs of this group, including the need for larger fonts, hearing and ambulatory assistance, pacing of testing sessions, and having protocols to address research-detected cognitive decline.

To the extent feasible, studies should include frailty measures and other markers of agerelated processes and biospecimens for correlative science analyses to elucidate biologically plausible mechanisms specific to older hosts (e.g., markers of cell senescence).

Analyses of data from older patients could consider use of trajectory analysis ${ }^{153}$ in addition to use of group means and changes in group means. Informative missing data on covariates and cognitive outcomes as well as the impact of practice effects will be especially important to consider when following older age groups longitudinally. As in other observational research, the analysts will need to consider the role of confounding due to the common factors affecting systemic treatment selection and those placing older women at risk for cognitive declines.

Across a variety of cancers and types of treatment, the magnitude of cognitive effect tends to vary by choice of control group; this has not been empirically evaluated in older patients, but should be even more important than in studies of younger patients. For instance, in several meta-analyses, the largest effects (medium to large effects based on SD-effect sizes) were noted when cancer patients were compared to population normative values; moderate changes were seen when patients were compared to healthy non-cancer controls matched on age and education. ${ }^{17,18,20,154,155}$ In studies of younger breast cancer patients, effects appear to be the smallest when patients are compared to their own baseline, pre-treatment function, ${ }^{154}$ although practice effects may account for some of the lack of effect if 
alternative forms of tests are not employed. As suggested by Ahles, Wefel and others, these average effects may mask meaningful declines among sub-groups. As they note, when declines in performance are combined with improved performance as a result of practice for the majority of patients, the effect of chemotherapy on cognitive declines may be underestimated. ${ }^{34,156}$

\section{Practice Implications}

From the preceding review it is apparent that there is a fairly strong body of evidence linking aging processes to cancer-related cognitive declines. But it is also clear that there are many unanswered questions. While the research community grapples with how to provide rigorous empiric evidence for older cancer patients, clinicians are faced every day with caring for the growing number of older cancer patients presenting to their practices. What then are the implications of what we think we know about cancer-related cognitive decline for the care of older breast (and other) cancer patients?

The obvious implication for oncology training is that it includes education on geriatric assessment and that geriatric assessments should be part of routine care since they can provide information on frailty phenotypes and reserve. ${ }^{157}$ The results of geriatric assessment could be used as a tool for identifying sub-groups of older patients who are likely to be at highest risk for cognitive decline after systemic therapy. This information could be used together with clinical data and results of tumor multi-gene profiles in discussions with patients about the balance of benefits and harms of systemic therapy. Geriatric assessment data could change treatment recommendations, especially when indications for systemic therapy are equivocal, since cognitive changes are among the symptoms most feared by older adults. ${ }^{158-161}$

Geriatric assessment could also be used to identify the population of "pre-frail" older cancer patients that might need close monitoring and intervention during and after cancer systemic therapy. In addition, our review suggests that interventions that prevent frailty and maintain function could be useful in preventing or ameliorating cognitive decline among cancer patients.

There is a relative paucity of human studies designed to evaluate interventions to treat cancer-related cognitive changes compared to the large body of literature describing the phenomenon, although there are data from animal models that are informing new approaches. Unfortunately, most studies in humans and animals have generally not included or not been focused on older patients (or animals). ${ }^{162}$ There are, however, studies in Alzheimer's disease with older patients that may have relevance to the cancer setting, including behavioral and pharmacological interventions. Existing interventions have reviewed elsewhere, ${ }^{163}$ and are briefly summarized briefly.

One prominent behavioral approach is cognitive training. In younger cancer patients, cognitive therapy, including rehearsing compensatory strategies was noted to improve cognitive function, ${ }^{164}$ but this effect was not noted in other studies. ${ }^{165}$ Similar interventions have also been successful in older Alzheimer's patients. ${ }^{166}$ A review of factors associated with prevention of age-related cognitive decline reported evidence that physical exercise and possibly diet could be efficacious behavioral interventions. ${ }^{166}$ Exercise has been protective of decline after chemotherapy in rodents. ${ }^{167}$ Increasing antioxidants via dietary change has been shown to be protective of cognitive decline in animal models. ${ }^{60}$ Interestingly, in preliminary trials with non-smoking, non-cancer patients with mild cognitive impairment, transdermal nicotine was safe and improved cognitive function, possibly via stimulation of nicotinic acetylcholine receptors. ${ }^{168}$ These data suggest the value of conducting trials to provide evidence to support incorporation of some 
of these approaches in to clinical care to preserve cognitive function in older cancer survivors.

There are several promising pharmacological interventions that have been tested largely in animal models. ${ }^{163}$ Fluoxetine have been shown in animal models to prevent behavioral and hippocampal deficits associated with older chemotherapy regimens, such as 5Flourouracil. ${ }^{169,170}$ These approaches have not yet been replicated in older animals, translated to clinical settings with humans, or tested for safety or interactions with chemotherapy efficacy. It will be important to include sufficient numbers of older patients when these studies are conducted. In human research, two studies have demonstrated the efficacy of modafinil, a psycho-stimulant, in improving memory and attention and reducing fatigue in cancer patients. ${ }^{171,172}$ Herbal compounds such as Gingko biloba are under evaluation in ongoing cancer trials ${ }^{163}$ and Alzheimer's treatment drugs have been examined in patients undergoing brain irradiation.

Given the parallels between aging, frailty and cognitive decline in cancer patients, it is also logical that interventions that prevent frailty could be useful as targets for older cancer survivors. These "anti-aging" models have been examined largely in animal models and include caloric restriction, rapamycin, protein aggregation inhibitors, and removal of senescent cells. ${ }^{9}$

As the validity of personalized medicine becomes more established, understanding the genetic profiles of older patients at the greatest risk for cognitive decline could also be useful in clinical decision-making about systemic therapy and risk of cognitive decline. These data could also contribute to the next generation of pharmacogenetic studies that investigate which medications best prevent cognitive effects in vulnerable women and which systemic therapies are most and least likely to lead to cognitive toxicity in older women. 173,174

\section{Conclusions}

There is a strong albeit non-universal body of literature supporting the phenomenon of cognitive decline after breast cancer and its systemic therapies. This side effect is likely to be only experienced by a sub-group of patients, and while risk factors have been identified, biological mechanisms and pathways have not been fully elucidated. From what we do know, it appears that there are common underlying processes at the intersection of cancer, aging and the frail phenotype. Geriatric assessment could be a useful tool to aid in treatment decision making and identify the sub-groups most vulnerable to adverse cognitive outcomes.

Given the demographic imperative of a rapidly growing older population, increasing cancer incidence with advancing age and the increasingly chronic nature of breast cancer, research in older cancer patients and survivors will be critical to providing the evidence for practice guidelines.

Thus, we recommend that designing and conducting basic science and population trials specifically for older cancer patients should receive high priority. These studies should include intermediate endpoints of relevance to this group, including cognitive function and trajectories of frailty. ${ }^{175-177}$ Clinicians and their older patients can advance the field by active encouragement of and participation in research designed to improve the care and outcomes of older cancer patients. 


\section{Acknowledgments}

This research was supported by the National Cancer Institute at the National Institutes of Health grant \#R01CA129769; also supported in part by the National Cancer Institute at the National Institutes of Health grants \# U10 CA 84131, R01CA 127617, and K05CA096940 to JSM; and the National Cancer Institute at the National Institutes of Health grant \#P30CA51008 to Lombardi Comprehensive Cancer Center (synergy developmental funds to JSM and JVM). The work of AJS and BCM was supported in part by R01 CA101318, P30 CA082709, and R25 CA117865, U54 RR025761, C06 RR020128, S10 RR027710, R01 AG019771, P30 AG010133, F30 AG039959, and U24AG021886. The work of RAS was supported by National Institutes of Health grant \#P30-AG13846 to Boston University Alzheimer's Disease Center. The work of AH was supported in part by National Institutes of Health grant \#U54 132378 and the Starr Foundation.

\section{References}

1. Surveillance, Epidemiology, and End Results (SEER) Program. National Cancer Institute, DCCPS; (www.seer.cancer.gov) SEER*Stat Database: Mortality-All COD, Aggregated with state, total U.S. (1969-2009)<Katrina/Rita Population Adjustment>-linked to county attributes-total U.S., 19692010 counties [Accessed May 1, 2012]

2. United States Census Bureau, U.S. Department of Commerce, Economics and Statistics Administration. [Accessed 2008] Population by age, sex, race and Hispanic and Latino origin for the United States. 2011. http://www.census.gov/population/www.cen2000/briefs/phc-t9/tables/ tab01.pdf

3. Silberfarb PM. Chemotherapy and cognitive defects in cancer patients. Annu Rev Med. 1983; 34:35-46. [PubMed: 6344764]

4. Eberhardt B, Dilger S, Musial F, Wedding U, Weiss T, Miltner WH. Short-term monitoring of cognitive functions before and during the first course of treatment. J Cancer Res Clin Oncol. 2006; 132:234-240. [PubMed: 16416107]

5. Ahles TA, Root JC, Ryan EL. Cancer- and cancer treatment-associated cognitive change: an update on the state of the science. J Clin Oncol. 2012; 30:3675-3686. [PubMed: 23008308]

6. Jim HS, Phillips KM, Chait $S$, et al. Meta-analysis of cognitive functioning in breast cancer survivors previously treated with standard-dose chemotherapy. J Clin Oncol. 2012; 30:3578-3587. [PubMed: 22927526]

7. Ahles TA, Saykin AJ, McDonald BC, et al. Longitudinal assessment of cognitive changes associated with adjuvant treatment for breast cancer: impact of age and cognitive reserve. J Clin Oncol. 2010; 28:4434-4440. [PubMed: 20837957]

8. Campisi J. Aging, Cellular Senescence, and Cancer. Annu Rev Physiol. 2012

9. Kirkland JL. Translating advances from the basic biology of aging into clinical application. Exp Gerontol. 2013; 48:1-5. [PubMed: 23237984]

10. Head D, Snyder AZ, Girton LE, Morris JC, Buckner RL. Frontal-hippocampal double dissociation between normal aging and Alzheimer's disease. Cereb Cortex. 2005; 15:732-739. [PubMed: 15371293]

11. Hedden T, Gabrieli JD. Healthy and pathological processes in adult development: new evidence from neuroimaging of the aging brain. Curr Opin Neurol. 2005; 18:740-747. [PubMed: 16280688]

12. Saykin AJ, Ahles TA, McDonald BC. Mechanisms of chemotherapy-induced cognitive disorders: neuropsychological, pathophysiological, and neuroimaging perspectives. Semin Clin Neuropsychiatry. 2003; 8:201-216. [PubMed: 14613048]

13. Conroy SK, McDonald BC, Smith DJ, et al. Alterations in brain structure and function in breast cancer survivors: effect of post-chemotherapy interval and relation to oxidative DNA damage. Breast Cancer Res Treat. 2013; 137:493-502. [PubMed: 23263697]

14. Siegel R, Naishadham D, Jemal A. Cancer statistics, 2013. CA Cancer J Clin. 2013; 63:11-30. [PubMed: 23335087]

15. American Cancer Society. Breast Cancer Facts \& Figures 2011-2012. Atlanta: American Cancer Society, Inc; [Assessed May 1, 2012]

16. Bender CM. Chemotherapy may have small to moderate negative effects on cognitive functioning. Cancer Treat Rev. 2006; 32:316-319. [PubMed: 16616991] 
17. Jansen SJ, Otten W, Baas-Thijssen MC, van de Velde CJ, Nortier JW, Stiggelbout AM. Explaining differences in attitude toward adjuvant chemotherapy between experienced and inexperienced breast cancer patients. J Clin Oncol. 2005; 23:6623-6630. [PubMed: 16170169]

18. Anderson-Hanley C, Sherman ML, Riggs R, Agocha VB, Compas BE. Neuropsychological effects of treatments for adults with cancer: a meta-analysis and review of the literature. J Int Neuropsychol Soc. 2003; 9:967-982. [PubMed: 14738279]

19. Correa DD, Ahles TA. Neurocognitive changes in cancer survivors. Cancer J. 2008; 14:396-400. [PubMed: 19060604]

20. Stewart A, Bielajew C, Collins B, Parkinson M, Tomiak E. A meta-analysis of the neuropsychological effects of adjuvant chemotherapy treatment in women treated for breast cancer. Clin Neuropsychol. 2006; 20:76-89. [PubMed: 16410227]

21. Small BJ, Rawson KS, Walsh E, et al. Catechol-O-methyltransferase genotype modulates cancer treatment-related cognitive deficits in breast cancer survivors. Cancer. 2011; 117:1369-1376. [PubMed: 21425136]

22. Ganz PA, Bower JE, Kwan L, et al. Does tumor necrosis factor-alpha (TNF-alpha) play a role in post-chemotherapy cerebral dysfunction? Brain Behav Immun. 2012

23. Ahles TA, Saykin AJ, Furstenberg CT, et al. Neuropsychologic impact of standard-dose systemic chemotherapy in long-term survivors of breast cancer and lymphoma. J Clin Oncol. 2002; 20:485493. [PubMed: 11786578]

24. Ahles TA, Saykin AJ, Noll WW, et al. The relationship of APOE genotype to neuropsychological performance in long-term cancer survivors treated with standard dose chemotherapy.

Psychooncology. 2003; 12:612-619. [PubMed: 12923801]

25. Koppelmans V, Breteler MM, Boogerd W, Seynaeve C, Gundy C, Schagen SB. Neuropsychological performance in survivors of breast cancer more than 20 years after adjuvant chemotherapy. J Clin Oncol. 2012; 30:1080-1086. [PubMed: 22370315]

26. Hurria A, Goldfarb S, Rosen C, et al. Effect of adjuvant breast cancer chemotherapy on cognitive function from the older patient's perspective. Breast Cancer Res Treat. 2006; 98:343-348. [PubMed: 16541322]

27. Freilich RJ, Delattre JY, Monjour A, DeAngelis LM. Chemotherapy without radiation therapy as initial treatment for primary CNS lymphoma in older patients. Neurology. 1996; 46:435-439. [PubMed: 8614508]

28. Yamada TH, Denburg NL, Beglinger LJ, Schultz SK. Neuropsychological outcomes of older breast cancer survivors: cognitive features ten or more years after chemotherapy. $\mathrm{J}$ Neuropsychiatry Clin Neurosci. 2010; 22:48-54. [PubMed: 20160209]

29. Hurria A, Lachs M. Is cognitive dysfunction a complication of adjuvant chemotherapy in the older patient with breast cancer? Breast Cancer Res Treat. 2007; 103:259-268. [PubMed: 17429718]

30. Hurria A, Rosen C, Hudis C, et al. Cognitive function of older patients receiving adjuvant chemotherapy for breast cancer: a pilot prospective longitudinal study. J Am Geriatr Soc. 2006; 54:925-931. [PubMed: 16776787]

31. Hutchinson AD, Hosking JR, Kichenadasse G, Mattiske JK, Wilson C. Objective and subjective cognitive impairment following chemotherapy for cancer: a systematic review. Cancer Treat Rev. 2012; 38:926-934. [PubMed: 22658913]

32. Vardy J, Rourke S, Tannock IF. Evaluation of cognitive function associated with chemotherapy: a review of published studies and recommendations for future research. J Clin Oncol. 2007; 25:2455-2463. [PubMed: 17485710]

33. Vardy J, Tannock I. Cognitive function after chemotherapy in adults with solid tumours. Crit Rev Oncol Hematol. 2007; 63:183-202. [PubMed: 17678745]

34. Wefel JS, Lenzi R, Theriault RL, Davis RN, Meyers CA. The cognitive sequelae of standard-dose adjuvant chemotherapy in women with breast carcinoma: results of a prospective, randomized, longitudinal trial. Cancer. 2004; 100:2292-2299. [PubMed: 15160331]

35. Vardy J, Wefel JS, Ahles T, Tannock IF, Schagen SB. Cancer and cancer-therapy related cognitive dysfunction: an international perspective from the Venice cognitive workshop. Ann Oncol. 2008; 19:623-629. [PubMed: 17974553] 
36. Fried LP, Tangen CM, Walston J, et al. Frailty in older adults: evidence for a phenotype. J Gerontol A Biol Sci Med Sci. 2001; 56:M146-M156. [PubMed: 11253156]

37. Sarkisian CA, Gruenewald TL, John BW, Seeman TE. Preliminary evidence for subdimensions of geriatric frailty: the MacArthur study of successful aging. J Am Geriatr Soc. 2008; 56:2292-2297. [PubMed: 19016933]

38. Avila-Funes JA, Amieva H, Barberger-Gateau P, et al. Cognitive impairment improves the predictive validity of the phenotype of frailty for adverse health outcomes: the three-city study. $\mathrm{J}$ Am Geriatr Soc. 2009; 57:453-461. [PubMed: 19245415]

39. Walston J, Hadley EC, Ferrucci L, et al. Research agenda for frailty in older adults: toward a better understanding of physiology and etiology: summary from the American Geriatrics Society/ National Institute on Aging Research Conference on Frailty in Older Adults. J Am Geriatr Soc. 2006; 54:991-1001. [PubMed: 16776798]

40. Sternberg SA, Wershof SA, Karunananthan S, Bergman H, Mark CA. The identification of frailty: a systematic literature review. J Am Geriatr Soc. 2011; 59:2129-2138. [PubMed: 22091630]

41. Whalley LJ, Deary IJ, Appleton CL, Starr JM. Cognitive reserve and the neurobiology of cognitive aging. Ageing Res Rev. 2004; 3:369-382. [PubMed: 15541707]

42. Vazzana R, Bandinelli S, Lauretani F, et al. Trail Making Test predicts physical impairment and mortality in older persons. J Am Geriatr Soc. 2010; 58:719-723. [PubMed: 20398153]

43. Taaffe DR, Harris TB, Ferrucci L, Rowe J, Seeman TE. Cross-sectional and prospective relationships of interleukin- 6 and C-reactive protein with physical performance in elderly persons: MacArthur studies of successful aging. J Gerontol A Biol Sci Med Sci. 2000; 55:M709-M715. [PubMed: 11129392]

44. Campisi J, d'Adda di FF. Cellular senescence: when bad things happen to good cells. Nat Rev Mol Cell Biol. 2007; 8:729-740. [PubMed: 17667954]

45. Nuciforo PG, Luise C, Capra M, Pelosi G, d'Adda di FF. Complex engagement of DNA damage response pathways in human cancer and in lung tumor progression. Carcinogenesis. 2007; 28:2082-2088. [PubMed: 17522062]

46. Tan ZS, Beiser AS, Vasan RS, et al. Inflammatory markers and the risk of Alzheimer disease: the Framingham Study. Neurology. 2007; 68:1902-1908. [PubMed: 17536046]

47. Kesler S, Janelsins M, Koovakkattu D, et al. Reduced hippocampal volume and verbal memory performance associated with interleukin- 6 and tumor necrosis factor-alpha levels in chemotherapytreated breast cancer survivors. Brain Behav Immun. 2012

48. Holohan KN, Lahiri DK, Schneider BP, Foroud T, Saykin AJ. Functional microRNAs in Alzheimer's disease and cancer: differential regulation of common mechanisms and pathway. Front Genet. 2012; 3:323. [PubMed: 23335942]

49. Risacher SL, Wudunn D, Pepin SM, et al. Visual contrast sensitivity in Alzheimer's disease, mild cognitive impairment, and older adults with cognitive complaints. Neurobiol Aging. 2013; 34:1133-1144. [PubMed: 23084085]

50. Risacher SL, Saykin AJ. Neuroimaging and Other Biomarkers for Alzheimers Disease: The Changing Landscape of Early Detection. Annu Rev Clin Psychol. 2013

51. Ahles TA, Saykin AJ. Candidate mechanisms for chemotherapy-induced cognitive changes. Nat Rev Cancer. 2007; 7:192-201. [PubMed: 17318212]

52. Silverman DH, Dy CJ, Castellon SA, et al. Altered frontocortical, cerebellar, and basal ganglia activity in adjuvant-treated breast cancer survivors 5-10 years after chemotherapy. Breast Cancer Res Treat. 2007; 103:303-311. [PubMed: 17009108]

53. McDonald BC, Conroy SK, Ahles TA, West JD, Saykin AJ. Gray matter reduction associated with systemic chemotherapy for breast cancer: a prospective MRI study. Breast Cancer Res Treat. 2010; 123:819-828. [PubMed: 20690040]

54. McDonald BC, Conroy SK, Smith DJ, West JD, Saykin AJ. Frontal gray matter reduction after breast cancer chemotherapy and association with executive symptoms: A replication and extension study. Brain Behav Immun. 2012

55. Ahles TA, Saykin AJ, McDonald BC, et al. Cognitive function in breast cancer patients prior to adjuvant treatment. Breast Cancer Res Treat. 2008; 110:143-152. [PubMed: 17674194] 
56. Ganguli M. A reduced risk of Alzheimer's disease in those who survive cancer. BMJ. 2012; 344:e1662. [PubMed: 22411921]

57. Driver JA, Beiser A, Au R, et al. Inverse association between cancer and Alzheimer's disease: results from the Framingham Heart Study. BMJ. 2012; 344:e1442. [PubMed: 22411920]

58. Driver JA, Lu KP. Pin1: a new genetic link between Alzheimer's disease, cancer and aging. Curr Aging Sci. 2010; 3:158-165. [PubMed: 20735350]

59. Irminger-Finger I. Science of cancer and aging. J Clin Oncol. 2007; 25:1844-1851. [PubMed: 17488982]

60. Seigers R, Fardell JE. Neurobiological basis of chemotherapy-induced cognitive impairment: a review of rodent research. Neurosci Biobehav Rev. 2011; 35:729-741. [PubMed: 20869395]

61. Dietrich J, Han R, Yang Y, Mayer-Proschel M, Noble M. CNS progenitor cells and oligodendrocytes are targets of chemotherapeutic agents in vitro and in vivo. J Biol. 2006; 5:22. [PubMed: 17125495]

62. Maccormick RE. Possible acceleration of aging by adjuvant chemotherapy: a cause of early onset frailty? Med Hypotheses. 2006; 67:212-215. [PubMed: 16546325]

63. Stemmer SM, Stears JC, Burton BS, Jones RB, Simon JH. White matter changes in patients with breast cancer treated with high-dose chemotherapy and autologous bone marrow support. AJNR Am J Neuroradiol. 1994; 15:1267-1273. [PubMed: 7976937]

64. Kawas C, Resnick S, Morrison A, et al. A prospective study of estrogen replacement therapy and the risk of developing Alzheimer's disease: the Baltimore Longitudinal Study of Aging. Neurology. 1997; 48:1517-1521. [PubMed: 9191758]

65. Yaffe K, Sawaya G, Lieberburg I, Grady D. Estrogen therapy in postmenopausal women: effects on cognitive function and dementia. JAMA. 1998; 279:688-695. [PubMed: 9496988]

66. Paganini-Hill A, Henderson VW. Estrogen replacement therapy and risk of Alzheimer disease. Arch Intern Med. 1996; 156:2213-2217. [PubMed: 8885820]

67. Ross JL, Roeltgen D, Stefanatos GA, et al. Androgen-responsive aspects of cognition in girls with Turner syndrome. J Clin Endocrinol Metab. 2003; 88:292-296. [PubMed: 12519868]

68. Ross JL, Roeltgen D, Feuillan P, Kushner H, Cutler GB Jr. Effects of estrogen on nonverbal processing speed and motor function in girls with Turner's syndrome. J Clin Endocrinol Metab. 1998; 83:3198-3204. [PubMed: 9745426]

69. Ross JL, Roeltgen D, Kushner H, Wei F, Zinn AR. The Turner syndrome-associated neurocognitive phenotype maps to distal Xp. Am J Hum Genet. 2000; 67:672-681. [PubMed: 10931762]

70. McEwen BS, Woolley CS. Estradiol and progesterone regulate neuronal structure and synaptic connectivity in adult as well as developing brain. Exp Gerontol. 1994; 29:431-436. [PubMed: 7925761]

71. Srivastava RA, Bhasin N, Srivastava N. Apolipoprotein E gene expression in various tissues of mouse and regulation by estrogen. Biochem Mol Biol Int. 1996; 38:91-101. [PubMed: 8932523]

72. Sherwin BB. Estrogen and cognitive aging in women. Neuroscience. 2006; 138:1021-1026. [PubMed: 16310965]

73. Lee, J. Understanding cognitive reserve through genetic epidemiology. In: Stern, Y., editor. Cognitive Reserve. New York, NY: Taylor \& Francis; 2006. p. 5-34.

74. Monastero R, Cefalu AB, Camarda C, et al. Association of estrogen receptor alpha gene with Alzheimer's disease: a case-control study. J Alzheimers Dis. 2006; 9:273-278. [PubMed: 16914837]

75. Unfer TC, Conterato GM, da Silva JC, Duarte MM, Emanuelli T. Influence of hormone replacement therapy on blood antioxidant enzymes in menopausal women. Clin Chim Acta. 2006; 369:73-77. [PubMed: 16472795]

76. Chisu V, Manca P, Zedda M, Lepore G, Gadau S, Farina V. Effects of testosterone on differentiation and oxidative stress resistance in C1300 neuroblastoma cells. Neuro Endocrinol Lett. 2006; 27:807-812. [PubMed: 17187012]

77. Lee DC, Im JA, Kim JH, Lee HR, Shim JY. Effect of long-term hormone therapy on telomere length in postmenopausal women. Yonsei Med J. 2005; 46:471-479. [PubMed: 16127770] 
78. Castellon SA, Ganz PA, Bower JE, Petersen L, Abraham L, Greendale GA. Neurocognitive performance in breast cancer survivors exposed to adjuvant chemotherapy and tamoxifen. $\mathrm{J}$ Clin Exp Neuropsychol. 2004; 26:955-969. [PubMed: 15742545]

79. Schilder CM, Seynaeve C, Beex LV, et al. Effects of tamoxifen and exemestane on cognitive functioning of postmenopausal patients with breast cancer: results from the neuropsychological side study of the tamoxifen and exemestane adjuvant multinational trial. J Clin Oncol. 2010; 28:1294-1300. [PubMed: 20142601]

80. Jenkins VA, Ambroisine LM, Atkins L, Cuzick J, Howell A, Fallowfield LJ. Effects of anastrozole on cognitive performance in postmenopausal women: a randomised, double-blind chemoprevention trial (IBIS II). Lancet Oncol. 2008; 9:953-961. [PubMed: 18768369]

81. Bender CM, Sereika SM, Brufsky AM, et al. Memory impairments with adjuvant anastrozole versus tamoxifen in women with early-stage breast cancer. Menopause. 2007; 14:995-998. [PubMed: 17898668]

82. Collins B, Mackenzie J, Stewart A, Bielajew C, Verma S. Cognitive effects of hormonal therapy in early stage breast cancer patients: a prospective study. Psychooncology. 2009; 18:811-821. [PubMed: 19085975]

83. Schilder CM, Eggens PC, Seynaeve C, et al. Neuropsychological functioning in postmenopausal breast cancer patients treated with tamoxifen or exemestane after AC-chemotherapy: crosssectional findings from the neuropsychological TEAM-side study. Acta Oncol. 2009; 48:76-85. [PubMed: 18777410]

84. Bender CM, Paraska KK, Sereika SM, Ryan CM, Berga SL. Cognitive function and reproductive hormones in adjuvant therapy for breast cancer: a critical review. J Pain Symptom Manage. 2001; 21:407-424. [PubMed: 11369162]

85. Ciocca DR, Roig LM. Estrogen receptors in human nontarget tissues: biological and clinical implications. Endocr Rev. 1995; 16:35-62. [PubMed: 7758432]

86. Shilling V, Jenkins V, Fallowfield L, Howell A. The effects of oestrogens and anti-oestrogens on cognition. Breast. 2001; 10:484-491. [PubMed: 14965628]

87. Deroo BJ, Korach KS. Estrogen receptors and human disease. J Clin Invest. 2006; 116:561-570. [PubMed: 16511588]

88. Kesler SR, Kent JS, O'Hara R. Prefrontal cortex and executive function impairments in primary breast cancer. Arch Neurol. 2011; 68:1447-1453. [PubMed: 22084128]

89. Joshi G, Aluise CD, Cole MP, et al. Alterations in brain antioxidant enzymes and redox proteomic identification of oxidized brain proteins induced by the anti-cancer drug adriamycin: implications for oxidative stress-mediated chemobrain. Neuroscience. 2010; 166:796-807. [PubMed: 20096337]

90. Shai L, Schulze MB, Manson JE, Rexrode KM, Stampfer MJ, et al. A prospective study of soluble tumor necrosis factor-alpha receptor II (sTNF-RII) and risk of coronary heart disease among women with type 2 diabetes. Diabetes Care. 2005; 28:1376-1382. [PubMed: 15920055]

91. Blasiak J, Arabski M, Krupa R, et al. Basal, oxidative and alkylative DNA damage, DNA repair efficacy and mutagen sensitivity in breast cancer. Mutat Res. 2004; 554:139-148. [PubMed: 15450412]

92. Chen Y, Jungsuwadee P, Vore M, Butterfield DA, St Clair DK. Collateral damage in cancer chemotherapy: oxidative stress in nontargeted tissues. Mol Interv. 2007; 7:147-156. [PubMed: 17609521]

93. Migliore L, Scarpato R, Coppede F, Petrozzi L, Bonuccelli U, Rodilla V. Chromosome and oxidative damage biomarkers in lymphocytes of Parkinson's disease patients. Int J Hyg Environ Health. 2001; 204:61-66. [PubMed: 11725348]

94. Migliore L, Fontana I, Trippi F, et al. Oxidative DNA damage in peripheral leukocytes of mild cognitive impairment and AD patients. Neurobiol Aging. 2005; 26:567-573. [PubMed: 15708428]

95. Brown K. Is tamoxifen a genotoxic carcinogen in women? Mutagenesis. 2009; 24:391-404. [PubMed: 19505894]

96. Harrison JF, Hollensworth SB, Spitz DR, Copeland WC, Wilson GL, LeDoux SP. Oxidative stress-induced apoptosis in neurons correlates with mitochondrial DNA base excision repair pathway imbalance. Nucleic Acids Res. 2005; 33:4660-4671. [PubMed: 16107556] 
97. Caldecott KW. DNA single-strand breaks and neurodegeneration. DNA Repair (Amst). 2004; 3:875-882. [PubMed: 15279772]

98. Rolig RL, McKinnon PJ. Linking DNA damage and neurodegeneration. Trends Neurosci. 2000; 23:417-424. [PubMed: 10941191]

99. Wilson CJ, Finch CE, Cohen HJ. Cytokines and cognition--the case for a head-to-toe inflammatory paradigm. J Am Geriatr Soc. 2002; 50:2041-2056. [PubMed: 12473019]

100. McAllister TW, Ahles TA, Saykin AJ, et al. Cognitive effects of cytotoxic cancer chemotherapy: predisposing risk factors and potential treatments. Curr Psychiatry Rep. 2004; 6:364-371. [PubMed: 15355759]

101. Corder EH, Saunders AM, Strittmatter WJ, et al. Gene dose of apolipoprotein E type 4 allele and the risk of Alzheimer's disease in late onset families. Science. 1993; 261:921-923. [PubMed: 8346443]

102. Farrer LA, Cupples LA, Haines JL, et al. Effects of age, sex, and ethnicity on the association between apolipoprotein E genotype and Alzheimer disease. A meta-analysis. APOE and Alzheimer Disease Meta Analysis Consortium. JAMA. 1997; 278:1349-1356. [PubMed: 9343467]

103. Laws SM, Clarnette RM, Taddei K, et al. APOE-epsilon4 and APOE -491A polymorphisms in individuals with subjective memory loss. Mol Psychiatry. 2002; 7:768-775. [PubMed: 12192621]

104. Nathoo N, Chetry R, van Dellen JR, Connolly C, Naidoo R. Apolipoprotein E polymorphism and outcome after closed traumatic brain injury: influence of ethnic and regional differences. $\mathrm{J}$ Neurosurg. 2003; 98:302-306. [PubMed: 12593615]

105. Porrata-Doria T, Matta JL, Acevedo SF. Apolipoprotein E Allelic Frequency Altered in Women with Early-onset Breast Cancer. Breast Cancer (Auckl ). 2010; 4:43-48. [PubMed: 20697532]

106. Moysich KB, Freudenheim JL, Baker JA, et al. Apolipoprotein E genetic polymorphism, serum lipoproteins, and breast cancer risk. Mol Carcinog. 2000; 27:2-9. [PubMed: 10642431]

107. Marzolini C, Paus E, Buclin T, Kim RB. Polymorphisms in human MDR1 (P-glycoprotein): recent advances and clinical relevance. Clin Pharmacol Ther. 2004; 75:13-33. [PubMed: 14749689]

108. Jenkins V, Atkins L, Fallowfield L. Does endocrine therapy for the treatment and prevention of breast cancer affect memory and cognition? Eur J Cancer. 2007; 43:1342-1347. [PubMed: 17499988]

109. Crivellari D, Sun Z, Coates AS, et al. Letrozole Compared With Tamoxifen for Elderly Patients With Endocrine-Responsive Early Breast Cancer: The BIG 1-98 Trial. J Clin Oncol. 2008

110. Goss PE, Ingle JN, Pater JL, et al. Late Extended Adjuvant Treatment With Letrozole Improves Outcome in Women With Early-Stage Breast Cancer Who Complete 5 Years of Tamoxifen. J Clin Oncol. 2008

111. Davies, C.; Pan, H.; Godwin, J., et al. For the Adjuvant Tamoxifen: Longer Against Shorter (ATLAS) Collaborative Group: ATLAS-10 v 5 years of adjuvant tamoxifen in ER+ disease: effects on outcome in the first and in the second decade after diagnosis. San Antonio Breast Cancer Symposium; December 5, 2012; 2012. Abstract S1-2. Presented

112. Davies C, Pan H, Godwin J, et al. Long-term effects of continuing adjuvant tamoxifen to 10 years versus stopping at 5 years after diagnosis of oestrogen receptor-positive breast cancer: ATLAS, a randomised trial. Lancet. 2012

113. Lindenberger U, Nagel IE, Chicherio C, Li SC, Heekeren HR, Backman L. Age-related decline in brain resources modulates genetic effects on cognitive functioning. Front Neurosci. 2008; 2:234244. [PubMed: 19225597]

114. Pang PT, Teng HK, Zaitsev E, et al. Cleavage of proBDNF by tPA/plasmin is essential for longterm hippocampal plasticity. Science. 2004; 306:487-491. [PubMed: 15486301]

115. Savitz J, Solms M, Ramesar R. The molecular genetics of cognition: dopamine, COMT and BDNF. Genes Brain Behav. 2006; 5:311-328. [PubMed: 16716201]

116. Egan MF, Kojima M, Callicott JH, et al. The BDNF val66met polymorphism affects activitydependent secretion of BDNF and human memory and hippocampal function. Cell. 2003; 112:257-269. [PubMed: 12553913] 
117. Hariri AR, Goldberg TE, Mattay VS, et al. Brain-derived neurotrophic factor val66met polymorphism affects human memory-related hippocampal activity and predicts memory performance. J Neurosci. 2003; 23:6690-6694. [PubMed: 12890761]

118. Pezawas L, Verchinski BA, Mattay VS, et al. The brain-derived neurotrophic factor val66met polymorphism and variation in human cortical morphology. J Neurosci. 2004; 24:10099-10102. [PubMed: 15537879]

119. Ganz, PA.; Castellon, SA.; Silverman, DHS.; Kwan, L.; Bower, JE.; Irwin, MR., et al. Does circulating tumor necrosis factor (TNF) play a role in postchemotherapy cerebral dysfunction in breast cancer survivors (BCS)?. Abstract presented at Annual Meeting of the American Society of Clinical Oncology; Chicago. June 3, 2011;

120. Cognitive complaints in breast cancer patients: associations with therapy and cytokine markers. Abstract presented at the International Cognition and Cancer Task Force Conference Meeting; Paris. March 16, 2012;

121. Han R, Yang YM, Dietrich J, Luebke A, Mayer-Proschel M, Noble M. Systemic 5-fluorouracil treatment causes a syndrome of delayed myelin destruction in the central nervous system. J Biol. 2008; 7:12. [PubMed: 18430259]

122. Wu H, Hait WN, Yang JM. Small interfering RNA-induced suppression of MDR1 (Pglycoprotein) restores sensitivity to multidrug-resistant cancer cells. Cancer Res. 2003; 63:15151519. [PubMed: 12670898]

123. Jamroziak K, Robak T. Pharmacogenomics of MDR1/ABCB1 gene: the influence on risk and clinical outcome of haematological malignancies. Hematology. 2004; 9:91-105. [PubMed: 15203864]

124. Meyers CA. How chemotherapy damages the central nervous system. J Biol. 2008; 7:11. [PubMed: 18439322]

125. Kalmijn S, Feskens EJ, Launer LJ, Kromhout D. Cerebrovascular disease, the apolipoprotein e4 allele, and cognitive decline in a community-based study of elderly men. Stroke. 1996; 27:2230 2235. [PubMed: 8969786]

126. Kilander L, Nyman H, Boberg M, Lithell H. Cognitive function, vascular risk factors and education. A cross-sectional study based on a cohort of 70-year-old men. J Intern Med. 1997; 242:313-321. [PubMed: 9366810]

127. van Exel E, de Craen AJ, Gussekloo J, et al. Association between high-density lipoprotein and cognitive impairment in the oldest old. Ann Neurol. 2002; 51:716-721. [PubMed: 12112077]

128. Keller JN. Age-related neuropathology, cognitive decline, and Alzheimer's disease. Ageing Res Rev. 2006; 5:1-13. [PubMed: 16084778]

129. Hurny C, Bernhard J, Coates AS, et al. Impact of adjuvant therapy on quality of life in women with node-positive operable breast cancer. International Breast Cancer Study Group. Lancet. 1996; 347:1279-1284. [PubMed: 8622502]

130. Peelle JE, Cusack R, Henson RN. Adjusting for global effects in voxel-based morphometry: gray matter decline in normal aging. Neuroimage. 2012; 60:1503-1516. [PubMed: 22261375]

131. Bergouignan L, Lefranc JP, Chupin M, Morel N, Spano JP, Fossati P. Breast cancer affects both the hippocampus volume and the episodic autobiographical memory retrieval. PLoS One. 2011; 6:e25349. [PubMed: 22016764]

132. Gunning-Dixon FM, Brickman AM, Cheng JC, Alexopoulos GS. Aging of cerebral white matter: a review of MRI findings. Int J Geriatr Psychiatry. 2009; 24:109-117. [PubMed: 18637641]

133. Helgeson VS, Snyder P, Seltman H. Psychological and physical adjustment to breast cancer over 4 years: identifying distinct trajectories of change. Health Psychol. 2004; 23:3-15. [PubMed: 14756598]

134. Jansen CE, Miaskowski CA, Dodd MJ, Dowling GA. A meta-analysis of the sensitivity of various neuropsychological tests used to detect chemotherapy-induced cognitive impairment in patients with breast cancer. Oncol Nurs Forum. 2007; 34:997-1005. [PubMed: 17878128]

135. Inagaki M, Yoshikawa E, Matsuoka Y, et al. Smaller regional volumes of brain gray and white matter demonstrated in breast cancer survivors exposed to adjuvant chemotherapy. Cancer. 2007; 109:146-156. [PubMed: 17131349] 
136. McDonald BC, Conroy SK, Ahles TA, West JD, Saykin AJ. Alterations in brain activation during working memory processing associated with breast cancer and treatment: a prospective functional magnetic resonance imaging study. J Clin Oncol. 2012; 30:2500-2508. [PubMed: 22665542]

137. Hosseini SM, Koovakkattu D, Kesler SR. Altered small-world properties of gray matter networks in breast cancer. BMC Neurol. 2012; 12:28. [PubMed: 22632066]

138. de Ruiter MB, Reneman L, Boogerd W, et al. Late effects of high-dose adjuvant chemotherapy on white and gray matter in breast cancer survivors: converging results from multimodal magnetic resonance imaging. Hum Brain Mapp. 2012; 33:2971-2983. [PubMed: 22095746]

139. Deprez S, Billiet T, Sunaert S, Leemans A. Diffusion tensor MRI of chemotherapy-induced cognitive impairment in non-CNS cancer patients: a review. Brain Imaging Behav. 2013

140. Saykin, A. Altered brain activation following systemic chemotherapy for breast cancer: Interim analysis from a prospective study. 34th Annual Meeting of International Neuropsychological Society; Boston, MA. 2006.

141. Scherling C, Collins B, Mackenzie J, Bielajew C, Smith A. Prechemotherapy differences in response inhibition in breast cancer patients compared to controls: a functional magnetic resonance imaging study. J Clin Exp Neuropsychol. 2012; 34:543-560. [PubMed: 22380580]

142. Tannock IF, Ahles TA, Ganz PA, van Dam FS. Cognitive impairment associated with chemotherapy for cancer: report of a workshop. J Clin Oncol. 2004; 22:2233-2239. [PubMed: 15169812]

143. Bruno J, Hosseini SM, Kesler S. Altered resting state functional brain network topology in chemotherapy-treated breast cancer survivors. Neurobiol Dis. 2012; 48:329-338. [PubMed: 22820143]

144. von ZT, Martin-Ruiz CM. Telomeres as biomarkers for ageing and age-related diseases. Curr Mol Med. 2005; 5:197-203. [PubMed: 15974873]

145. Schroder CP, Wisman GB, de Jong S, et al. Telomere length in breast cancer patients before and after chemotherapy with or without stem cell transplantation. Br J Cancer. 2001; 84:1348-1353. [PubMed: 11355946]

146. Lahav M, Uziel O, Kestenbaum M, et al. Nonmyeloablative conditioning does not prevent telomere shortening after allogeneic stem cell transplantation. Transplantation. 2005; 80:969976. [PubMed: 16249747]

147. Flanary BE, Streit WJ. Progressive telomere shortening occurs in cultured rat microglia, but not astrocytes. Glia. 2004; 45:75-88. [PubMed: 14648548]

148. Velarde, MC.; Demaria, M.; Campisi, J. Senescent cells and their secretory phenotype as targets for cancer therapy. In: Extermann, M., editor. Cancer and Aging. From Bench to Clinics. Interdiscipl Top Gerontol. Basel: Karger; 2013.

149. Gavrilov LA, Gavrilova NS. The reliability theory of aging and longevity. J Theor Biol. 2001; 213:527-545. [PubMed: 11742523]

150. Wefel JS, Saleeba AK, Buzdar AU, Meyers CA. Acute and late onset cognitive dysfunction associated with chemotherapy in women with breast cancer. Cancer. 2010; 116:3348-3356. [PubMed: 20564075]

151. Wefel JS, Vardy J, Ahles T, Schagen SB. International Cognition and Cancer Task Force recommendations to harmonise studies of cognitive function in patients with cancer. Lancet Oncol. 2011; 12:703-708. [PubMed: 21354373]

152. Stern Y. Cognitive reserve in ageing and Alzheimer's disease. Lancet Neurol. 2012; 11:10061012. [PubMed: 23079557]

153. Gill TM, Gahbauer EA, Han L, Allore HG. Trajectories of disability in the last year of life. N Engl J Med. 2010; 362:1173-1180. [PubMed: 20357280]

154. Jim H, Rodin G, Ahles TA. Long-term effects of chemo on the cognitive function of cancer patients. Oncology (Williston Park). 2012; 26:1012, 1014, 1042. [PubMed: 23330339]

155. Falleti MG, Sanfilippo A, Maruff P, Weih L, Phillips KA. The nature and severity of cognitive impairment associated with adjuvant chemotherapy in women with breast cancer: a meta-analysis of the current literature. Brain Cogn. 2005; 59:60-70. [PubMed: 15975700] 
156. Rodin G, Ahles TA. Accumulating evidence for the effect of chemotherapy on cognition. J Clin Oncol. 2012; 30:3568-3569. [PubMed: 22927529]

157. Mohile S, Dale W, Hurria A. Geriatric oncology research to improve clinical care. Nat Rev Clin Oncol. 2012; 9:571-578. [PubMed: 22825377]

158. Muss HB, Biganzoli L, Sargent DJ, Aapro M. Adjuvant therapy in the elderly: making the right decision. J Clin Oncol. 2007; 25:1870-1875. [PubMed: 17488985]

159. Friedenberg RM. Dementia: one of the greatest fears of aging. Radiology. 2003; 229:632-635. [PubMed: 14657300]

160. West RL, Bagwell DK, Dark-Freudeman A. Self-Efficacy and Memory Aging: The Impact of a Memory Intervention Based on Self-Efficacy. Neuropsychol Dev Cogn B Aging Neuropsychol Cogn. 2007:1-28. [PubMed: 17164187]

161. Burdette-Radoux S, Muss HB. Adjuvant chemotherapy in the elderly: whom to treat, what regimen? Oncologist. 2006; 11:234-242. [PubMed: 16549807]

162. Ferguson, RJ.; McDonald, BC.; Saykin, A.; Ahles, TA. Eastern Main Medical Center. Brain structure and function differences in monozygotic twins: possible effects of breast cancer chemotherapy. 2007.

163. Fardell JE, Vardy J, Johnston IN, Winocur G. Chemotherapy and cognitive impairment: treatment options. Clin Pharmacol Ther. 2011; 90:366-376. [PubMed: 21814191]

164. Ferguson RJ, Ahles TA, Saykin AJ, et al. Cognitive-behavioral management of chemotherapyrelated cognitive change. Psychooncology. 2006

165. Poppelreuter M, Weis J, Bartsch HH. Effects of specific neuropsychological training programs for breast cancer patients after adjuvant chemotherapy. J Psychosoc Oncol. 2009; 27:274-296. [PubMed: 19337933]

166. Okura T, Plassman BL, Steffens DC, Llewellyn DJ, Potter GG, Langa KM. Prevalence of neuropsychiatric symptoms and their association with functional limitations in older adults in the United States: the aging, demographics, and memory study. J Am Geriatr Soc. 2010; 58:330 337. [PubMed: 20374406]

167. Fardell JE, Vardy J, Shah JD, Johnston IN. Cognitive impairments caused by oxaliplatin and 5fluorouracil chemotherapy are ameliorated by physical activity. Psychopharmacology (Berl). 2012; 220:183-193. [PubMed: 21894483]

168. Newhouse P, Kellar K, Aisen P, et al. Nicotine treatment of mild cognitive impairment: a 6month double-blind pilot clinical trial. Neurology. 2012; 78:91-101. [PubMed: 22232050]

169. Lyons L, ElBeltagy M, Bennett G, Wigmore P. Fluoxetine counteracts the cognitive and cellular effects of 5-fluorouracil in the rat hippocampus by a mechanism of prevention rather than recovery. PLoS One. 2012; 7:e30010. [PubMed: 22272269]

170. ElBeltagy M, Mustafa S, Umka J, et al. Fluoxetine improves the memory deficits caused by the chemotherapy agent 5-fluorouracil. Behav Brain Res. 2010; 208:112-117. [PubMed: 19914299]

171. Kohli S, Fisher SG, Tra Y, et al. The effect of modafinil on cognitive function in breast cancer survivors. Cancer. 2009; 115:2605-2616. [PubMed: 19309747]

172. Lundorff LE, Jonsson BH, Sjogren P. Modafinil for attentional and psychomotor dysfunction in advanced cancer: a double-blind, randomised, cross-over trial. Palliat Med. 2009; 23:731-738. [PubMed: 19648224]

173. Nelson CJ, Nandy N, Roth AJ. Chemotherapy and cognitive deficits: mechanisms, findings, and potential interventions. Palliat Support Care. 2007; 5:273-280. [PubMed: 17969831]

174. Roses AD, Saunders AM, Huang Y, Strum J, Weisgraber KH, Mahley RW. Complex diseaseassociated pharmacogenetics: drug efficacy, drug safety, and confirmation of a pathogenetic hypothesis (Alzheimer's disease). Pharmacogenomics J. 2007; 7:10-28. [PubMed: 16770341]

175. Muss HB, Berry DA, Cirrincione CT, et al. Adjuvant chemotherapy in older women with earlystage breast cancer. N Engl J Med. 2009; 360:2055-2065. [PubMed: 19439741]

176. Ganz PA. Host factors, behaviors, and clinical trials: opportunities and challenges. J Clin Oncol. 2012; 30:2817-2819. [PubMed: 22753909]

177. Scher KS, Hurria A. Under-representation of older adults in cancer registration trials: known problem, little progress. J Clin Oncol. 2012; 30:2036-2038. [PubMed: 22547597] 

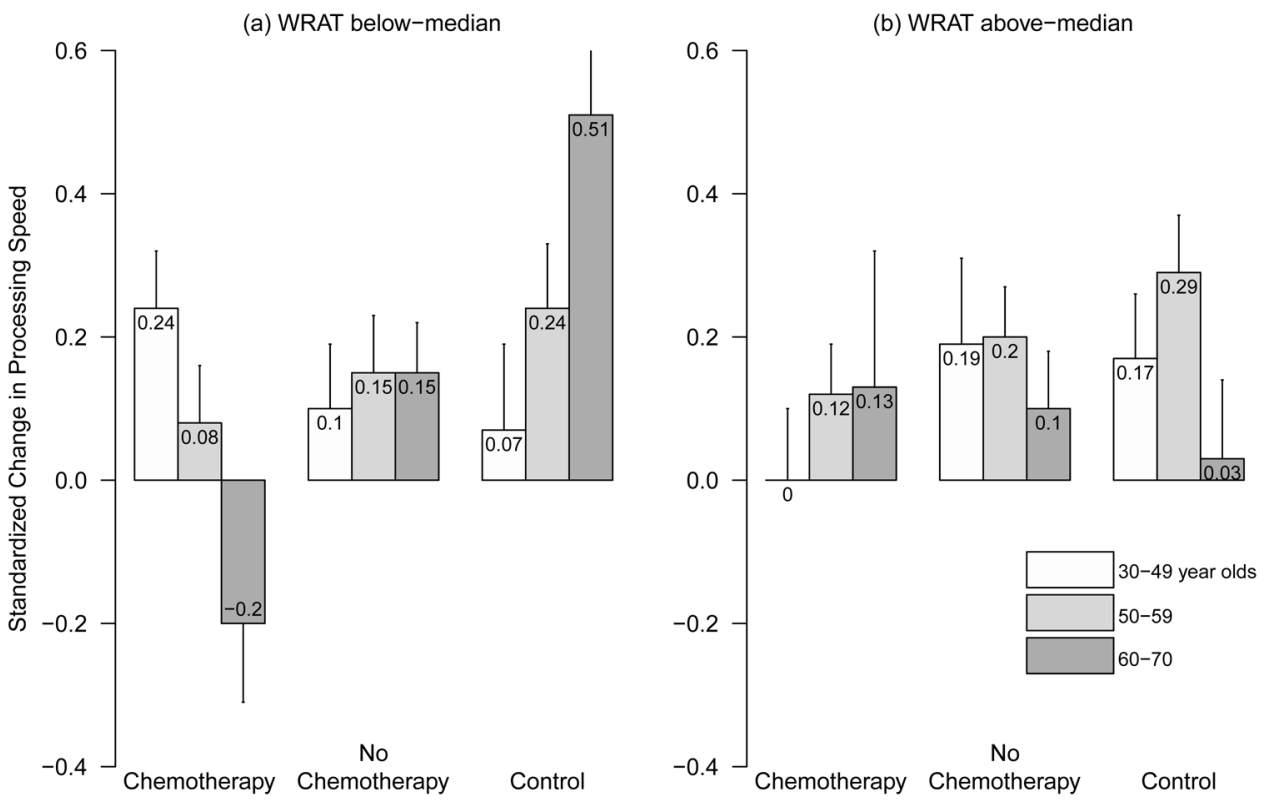

Figure 1.

Change in Processing Speed by Treatment, Age group, and Cognitive Reserve Among Breast Cancer Patients

Pre- to post-treatment change in processing speed by treatment, age groups, and level of cognitive reserve (assessed by the Wide Range Achievement Test (WRAT)-Reading). Reprinted with permission from Ahles et al 2012, Journal of Clinical Oncology 5 


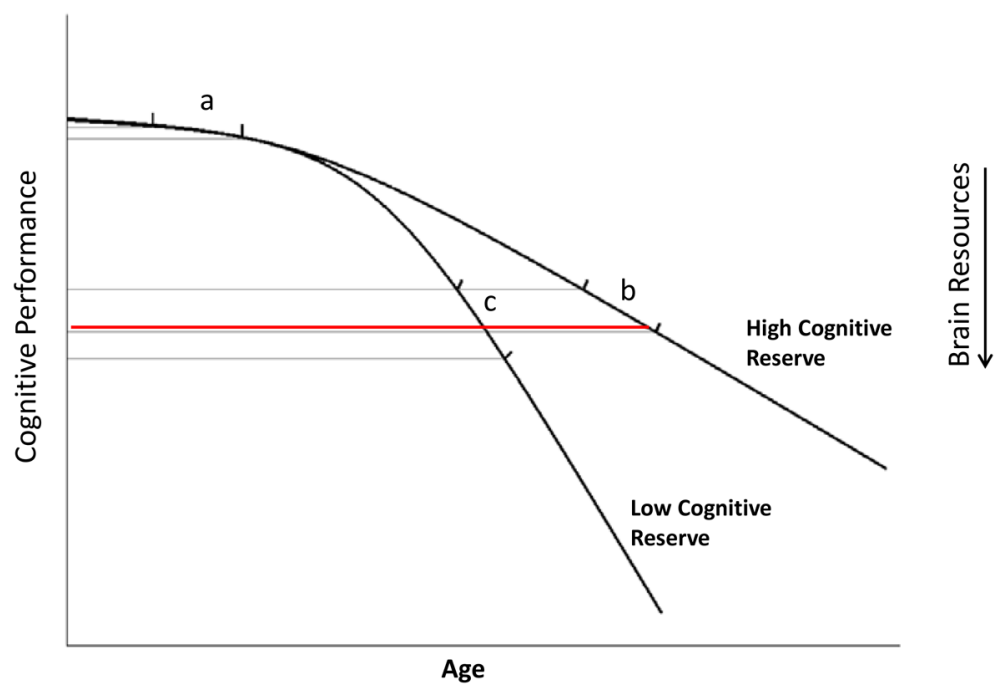

Figure 2.

Impact of Change in Brain Resources and Frailty Levels on Cognitive Performance by Age The same change in brain resources can have a minimal effect on cognitive performance in a young adult (a), a moderate effect in an older adult with high cognitive reserve (b) and a greater effect on an older adult with low cognitive reserve (c). Likewise, the same change in frailty level will have differential effects on the individual as a function of overall system reserve.

Adapted and reprinted with permission from Ahles et al, Psychooncology 201224 


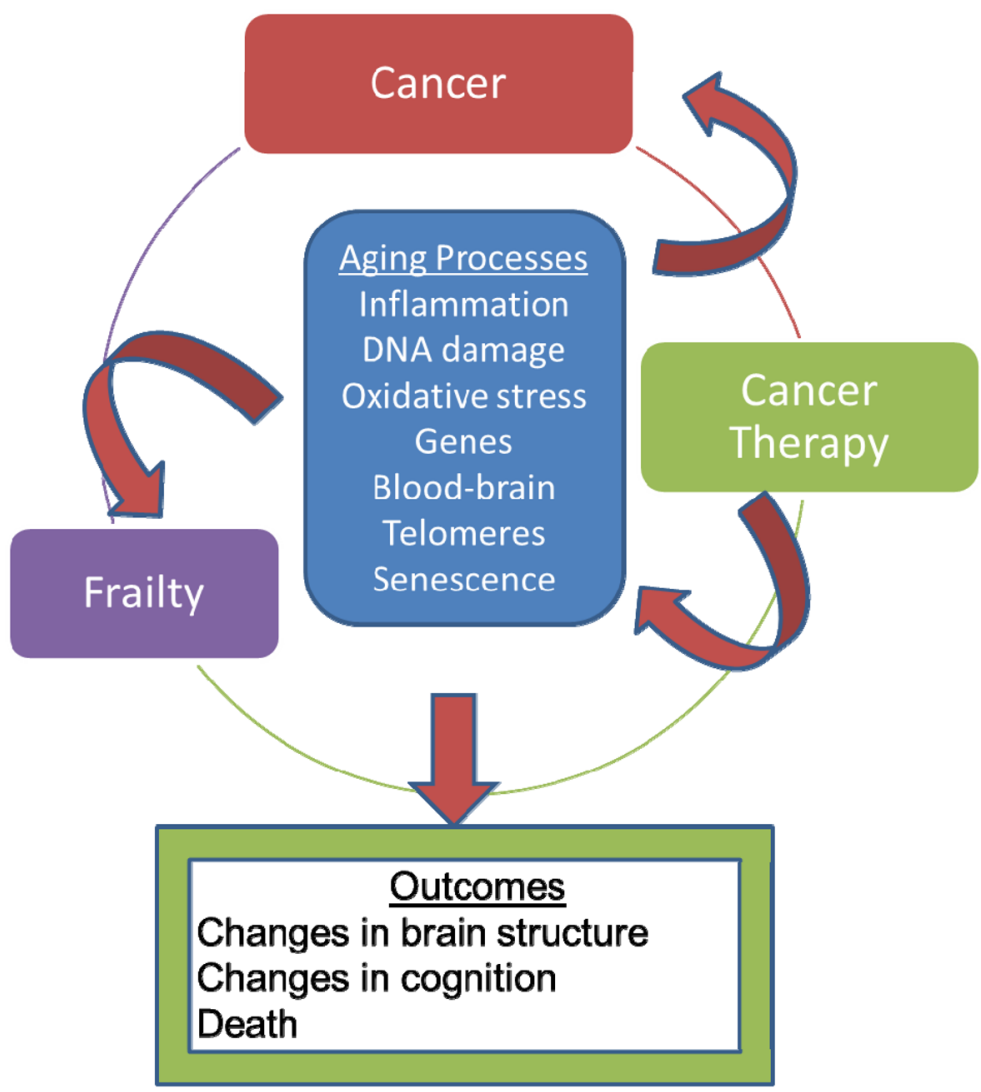

Figure 3.

Postulated Common Underlying Aging Processes Associated with Frailty, Cancer and Cancer Systemic Therapy and their Impact on Cognitive Outcomes 


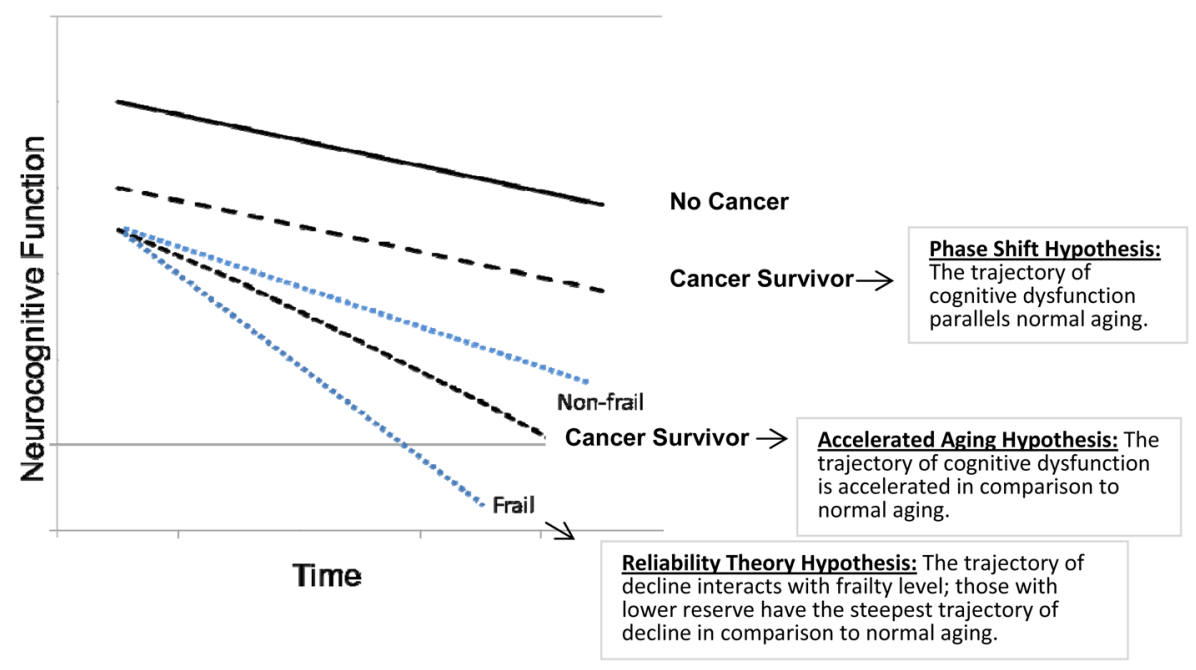

Figure 4.

Trajectories of Cognitive Decline Based on Theories of Aging and Frailty Phenotype Adapted from Ahles et al, 2012 Journal of Clinical Oncology 5 


\section{Table 1}

Domains of Cognitive Function Frequently Affect by Cancer and Cancer Systemic Therapy and their Implications for Daily Activities in Older Cancer Patients

\begin{tabular}{|lll|}
\hline Domain & Common Tests & Examples of Impact on Functioning \\
\hline $\begin{array}{l}\text { Executive Functioning, } \\
\text { Working Memory, } \\
\text { Psychomotor Speed }\end{array}$ & $\begin{array}{l}\text { Trailmaking Parts A \& B, Digit Symbol, Controlled } \\
\text { Oral Word Association Test (COWAT), NAB Driving } \\
\text { Scenes, Timed Instrumental Activities of Daily Living } \\
\text { (TIADL), NAB Figure Drawing }\end{array}$ & $\begin{array}{l}\text { Ability to organize activities, arrive on time, make } \\
\text { plans and decisions, correct errors and } \\
\text { conceptualize. }\end{array}$ \\
\hline Attention & NAB Digits Forward, NAB Digits Backward & $\begin{array}{l}\text { Ability to pay attention to new information and } \\
\text { process the information quickly. }\end{array}$ \\
\hline Language & Boston Naming Test, Category Fluency & Ability to fluently bring words to mind. \\
\hline Learning and Memory & $\begin{array}{l}\text { Logical Memory I and II Wechsler Memory Scale } \\
\text { (WMS-4), NAB List Learning }\end{array}$ & Ability to learn or recall new information. \\
\hline Visual spatial & NAB Figure Drawing Copy Subscale & $\begin{array}{l}\text { Ability to integrate visual information with motor } \\
\text { activities. }\end{array}$ \\
\hline
\end{tabular}

